\title{
MEGFOGÓFEJ ÉRINTKEZÉSI VISZONYAINAK OPTIMALIZÁLÁSA
}

\author{
Páczelt István \\ professzor emeritus, Miskolci Egyetem, Müszaki Mechanikai Intézet \\ 3515 Miskolc, Miskolc-Egyetemváros, e-mail: mechpacz@uni-miskolc.hu \\ Baksa Attila \\ egyetemi docens, Miskolci Egyetem, Müszaki Mechanikai Intézet \\ 3515 Miskolc, Miskolc-Egyetemváros, e-mail: mechab@uni-miskolc.hu
}

\begin{abstract}
Összefoglalás
Jelen munka az érintkezési nyomás részleges vezérlési technikájának segitségével oldja meg egy vizsgált tartóbélyeg és egy megfogó szerkezet elemei között fellépö érintkezési nyomás eloszlásának problémáját. A testek közötti kezdeti hézagot iteráció segitségével határoztuk meg, a résztvevö testek között végig érintkezést feltételezve. A megoldáshoz hatásfüggvények meghatározása is szükséges.
\end{abstract}

Kulcsszavak: rugalmasságtan, szerkezet optimalizálás, érintkezési optimalizálási feladat.

\begin{abstract}
In this paper some contact optimization problems are presented for a holder of a beam-punch elastic system, using the method of partially controlled contact pressure. Assuming full contact along the contact domain the problem is examined by iteration using the influence functions. The initial gap between the bodies is computed during the optimization.
\end{abstract}

Keywords: theory of elasticity, structural optimization, contact optimization problems

\section{Bevezetés}

Az érintkezési feladatokhoz köthető optimalizálási problémákkal számos pubikáció foglakozik. E munkák két nagy csoportba bonthatók. Egyrészt a kinematikai mennyiségek optimalizálása a cél [1], míg a máskor a dinamikai mennyiségek szerepelnek. A kérdés matematikai aspektusait a [2, 3, 4] könyvek tartalmazzák. Az általunk kidolgozott érintkezési nyomás részleges vezérlésének gondolata [5], a 2D és 3D-os optimalizálási munkáknál [6] nagyon hatékony eszköznek bizonyultak. Meg kell említeni, hogy a vezérlési technikát az ún. állandósult kopási állapotnál kialakuló kopott felület alakjának a meghatározásakor is fel lehet használni, lásd pl. [7, 8].

Érintkezési feladatokkal foglalkozó nagyszámú publikáció közül a numerikus technikát is alkalmazó Johnson [9], Kalker [10], Konyukhov [11] és Wriggers [12] által írt könyvek emelendők ki.

A [7, 8] publikációkat követve, két rugalmas testből $B_{\alpha}(\alpha=1,2)$ felépített rendszer érintkezési feladatát fogjuk vizsgálni. Az esetek döntő többségében feltételezzük, hogy a $B_{1}$ test kismértékü, merevtestszerü mozgást végez, míg a másik $B_{2}$ testnek nincs merevtestszerü mozgása.

\section{2. Érintkezési feltételek}

A testek között az $S_{c}$ feltételezett érintkezési tartományban az érintkezési felület normálisának irányában érintkezés van, ha az alakváltozás után kialakuló rés 


$$
d=u_{n}^{(2)}-u_{n}^{(1)}+g=0 \text { és az érintkezési nyomás } p_{n} \geq 0, x \in \Omega_{p},
$$

Rés/hézag van a testek között, ha

$$
d=u_{n}^{(2)}-u_{n}^{(1)}+g>0 \text { és } p_{n}=0, x \in \Omega_{0}
$$

vagyis

$$
p_{n} d=0, x \in S_{c} .
$$

Az (1) és (2) egyenletekben $u_{n}^{(i)}$ jelöli az $i$. test normálirányú elmozdulását, míg $g$ a kezdeti hézagot. A fentieket az irodalom Signorini-féle érintkezési feltételeknek nevezi.

Az optimalizálási feladatnál [5, 6] szerint elő fogjuk írni a nyomás lefutás át, vagyis

$$
p_{n}(x)=c(x) p_{n, \max }, x \in S_{c, v e z e ́ r e l t}
$$

az ún. vezérelt altartományon , míg a többi részen

$$
\chi=c(x) p_{n, \max }-p_{n}(x) \geq 0, x \in S_{c, \text { nem vezérelt }} .
$$

\section{Tartó terhelése}

Vizsgáljuk az 1. ábrán lévő prizmatikus tartót, melynél a $d$ értéket a $H^{(i)}(x, s)$ hatásfüggvények felhasználásával $u_{n}^{(i)}\left(p_{n}\right)=\int_{S_{c}} H^{(i)}(x, s) p_{n}(s) d s$ alakban írhatjuk fel:

$$
d=\left(u_{n}^{(2)}\left(p_{n}\right)+u_{n, \text { load }}^{(2)}\right)-\left(u_{n}^{(1)}\left(p_{n}\right)+\lambda\right)+g^{(0)} \geq 0
$$

ahol $\lambda$ adja az 1 jelü test merevtestszerű eltolódását (feltételezzük, hogy az csak eltolódik). Mivel a nyomás lefutását elöírjuk, a $c(x)$ vezérlő függvényen keresztül, feladatunk a bélyeg ( $B_{1}$ test) és a tartó közötti rés/kezdeti hézag meghatározása. A megoldáshoz előírjuk a $d=0$ értéket. A számítási algoritmust [13] tartalmazza. A megoldáshoz általában néhány iterációval jutunk el.

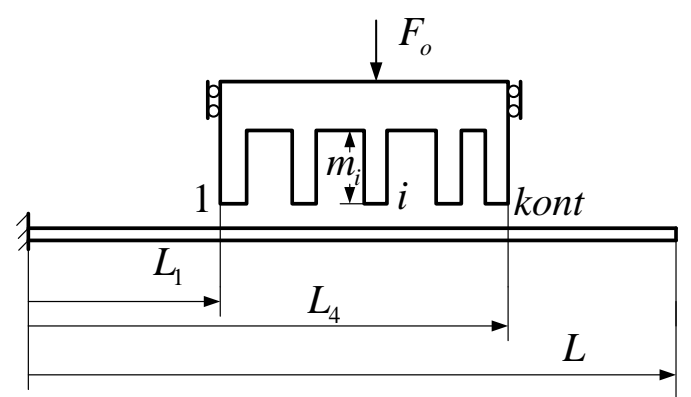

1. ábra. Az $F_{0}$ eröt kont számú fogon keresztül adjuk át a tartóra. 
Az eredményeket a 2. ábrán személtettük. Itt $F_{0}=10 \mathrm{kN}, L=900 \mathrm{~mm}, E=2 \times 10^{5} \mathrm{MPa}, I=166,66 \mathrm{~mm}^{4}$, $k o n t=23$, és a fogak felülete $A=100 \mathrm{~mm}^{2}$. Háromfajta vezérlő függvénnyel vizsgáltuk meg a feladatot (lásd 2. ábra). A legkisebb kontakt erőket a $c(x)=1$ vezérlésnél kapjuk.

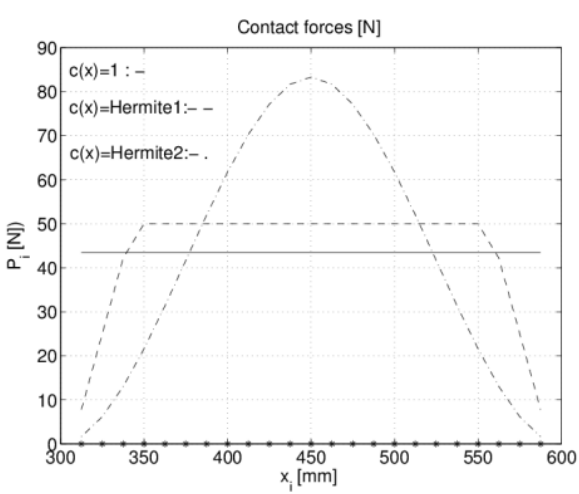

a)

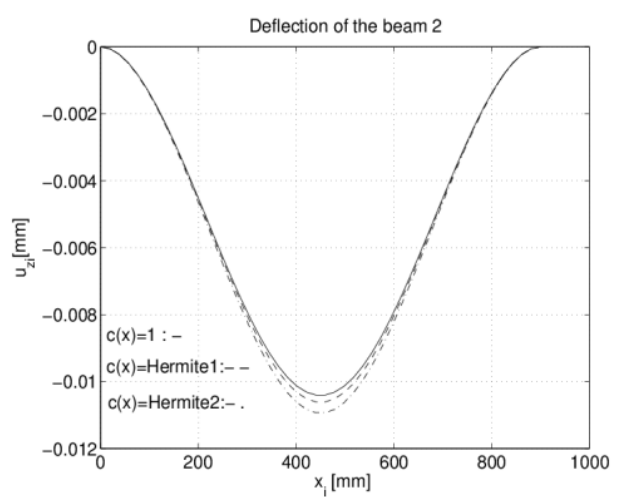

b)

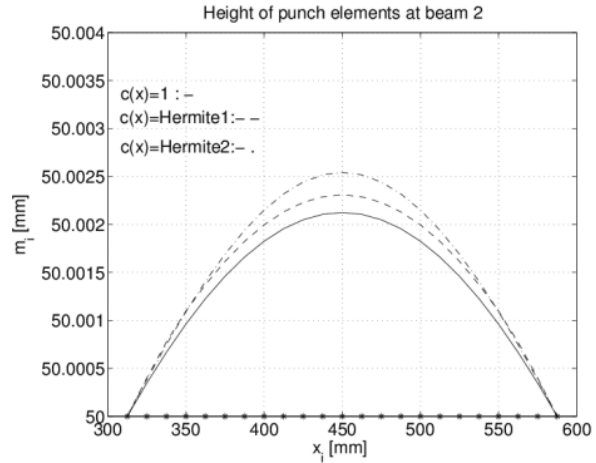

c)

2. ábra. Az elsö optimalizációs feladat eredménye, a) Vezérlö függvények: $L_{1}=300 \mathrm{~mm}, L_{4}=600 \mathrm{~mm}$, b) a tartó lehajlása, c) az optimalizált fog magasságok.

\section{Csőmegfogó szerkezet optimalizálása}

A gyakorlati életben találkozunk olyan feladattal, (pl. az olajbányászatban) amikor is a fúrásnál a földbe helyezendő csöveket meg kell fogni, majd a már földben lévőhöz csatlakoztatni és utána a fúrást tovább folytatni. Nagy súlyú csövet kell biztonságosan megfogni (lásd 3. ábra). A jelen példa a pofák kialakítására tesz javaslatot, különböző mechanikai modelleket felhasználva.

A $Q$ súlyú csövet három pofa $P_{f i} \mathrm{i}=1,2,3$ segítségével rögzítjük, oly módon, hogy a pofákat a kúpos felület mentén lefelé mozdítjuk el $F_{0}$ erő segítségével. Célunk, hogy a cső és a pofák „körmei” között egyenletes érintkezési nyomás jöjjön létre.

Többfajta mechanikai modellt építünk fel. Az első modellnél a pofákat síkfeszültségi állapotban vizsgáltuk, és a kúpos részt merevnek feltétleztük. A második modellnél a kúpos rész már rugalmas alakváltozásra képes. A harmadik esetben a testeket 3D-s modellként kezeljük. A pofa egyensúlyi viszonyaiból a 4. ábrán lévő erődiagram következik. Itt feltételezzük, hogy a cső és a pofa között $\mu$ a súrlódási tényező értéke, míg a pofa és az azt megtámasztó kúpos felület között $\mu_{s}$ a súrlódási tényező. A pofára $F_{0}$ erö hat, a megtámasztási felületen a 
reakció erő értéke $F_{s}$, a pofa fogai és a cső közötti érintkezési erők eredője $F_{\text {cont }}$. Ekkor feltételezzük, hogy a határhelyzetben a súrlódóerő irányát is figyelembe véve, az érintkezési erők (a pofák fogai és a cső között) a $\mu$ által meghatározott súrlódási kúp palástján helyezkednek el. A csövet terhelö $Q$ ismeretében, a $Q=3 \mu F_{\text {cont,n }}$ egyenletből az $F_{c o n t, n}$ normál erő kiszámítható, majd az erődiagramból az $F_{0}$ is.

Feltételezve, hogy a fogak normál irányú terhelése az

$$
F_{n}^{\text {fog }}=F_{\text {cont }, n} / \text { kont }
$$

míg az érintkezési nyomás a

$$
p_{n}=F_{n}^{f o g} / A_{f o g}=F_{n}^{f o g} / a b
$$

egyenletek szerint számítható.

A végeselem-modellből kiszámolt hatásfüggvények révén a $d=0$ egyenletből a kezdeti hézagok már meghatározhatók lesznek.
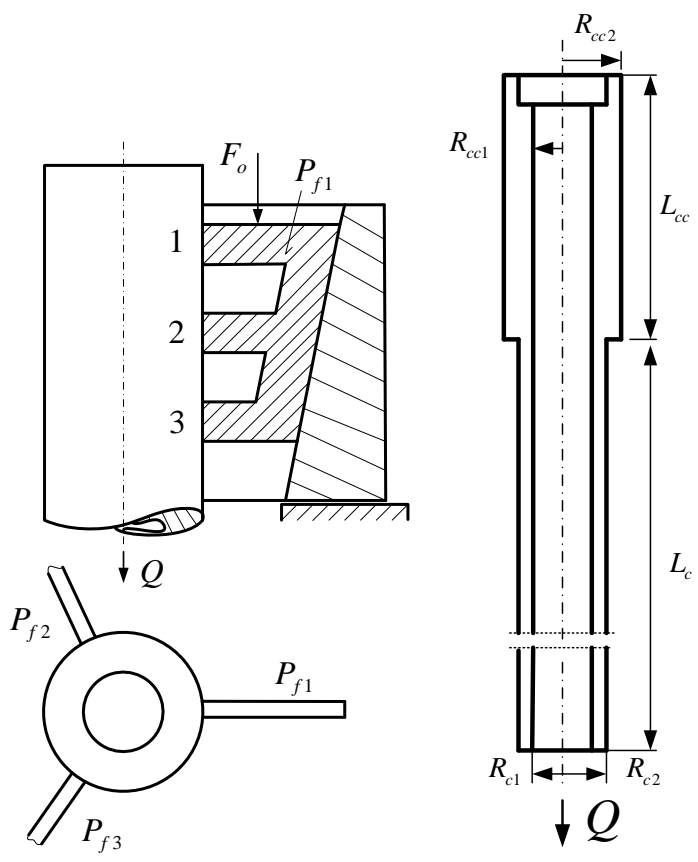

3. ábra. A cső pofás megfogása.

Vegyük fel az alábbi konkrét geometriai és anyagállandó adatokat:

Sürüség: $\rho=7,89 \mathrm{~kg} / \mathrm{dm}^{3}$, Young modulus $E=2 \times 10^{5} \mathrm{MPa}$, súrlódási tényezők: $\mu=0,25, \mu_{s}=0,2$; Poisson tényező $v=0,3$.

A megfogó pofa adatai:

$a=17,431 \mathrm{~mm}, \quad b=42,5 \mathrm{~mm} ; f=10 ; c=52,5 \mathrm{~mm} ; d=157,734 \mathrm{~mm} ; \alpha=20^{\circ}, \quad m_{1}=96 \mathrm{~mm}, \quad$ magassága: $m_{\text {pofa }}=4 b+3 f=200 \mathrm{~mm}$.

Cső adatai: $R_{c c 1}=80 \mathrm{~mm} ; R_{c c 2}=100 \mathrm{~mm} ; R_{c 1}=80 \mathrm{~mm} ; R_{c 2}=90 \mathrm{~mm} ; L_{c c}=0,4 \mathrm{~m} ; L_{c}=9,6 \mathrm{~m}$

így a keresztmetszetek: $A_{c}=5341 \mathrm{~mm}^{2}, A_{c c}=11310 \mathrm{~mm}^{2}$, a nehézségi gyorsulás: $g=9,81 \mathrm{~m} / \mathrm{s}^{2}$. A cső folyóméter súlya: $Q_{p}=\left(A_{c c} L_{c c}+A_{c} L_{c}\right) \cdot 10^{3} \cdot\left(\rho 10^{6}\right) \cdot g=4318 \mathrm{~N}$, 
100 méter súlya: $Q_{100}=10 \cdot Q_{p} \cdot F_{\text {cont }, n}=Q_{100} /(3 \mu)=57580,78 \mathrm{~N}$,

Az erődiagramból számítható további erők:

$$
F_{s}=F_{c o n t, n} / \cos (\alpha+\beta), F_{s, n}=F_{s} \cos \beta, F_{0}=F_{s n}\left(\sin \alpha+\mu_{s} \cos \alpha\right)-\mu F_{c o n t, n} .
$$

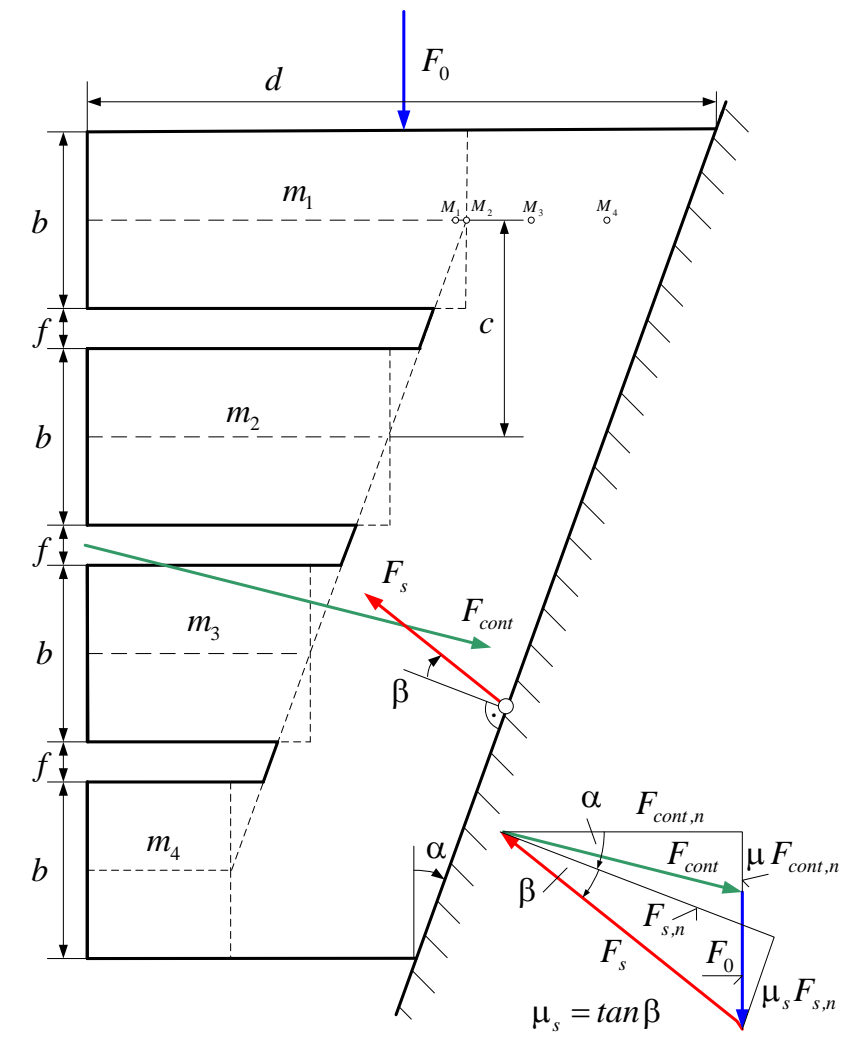

\section{4. ábra. Pofák síkfeszültségi állapotban (1. modell)}

A 4 fognál állandó $p_{n}$ nyomást feltételezve, figyelembe véve, hogy $F_{c o n t, n}=57580,78 \mathrm{~N}, p_{n}=19,43 \mathrm{MPa}$, továbbá $F_{s, n}=60,09 \mathrm{kN}, F_{0}=20,63 \mathrm{kN}$ a maximális redukált feszültség a kontakt tartományban $\sigma_{\text {red }}=42 \mathrm{MPa}$. Az optimalizálás után kapott kezdeti hézagot a 5b. ábra mutatja be merev alátámasztásnál (folytonos vonal), rugalmas kúpos testnél (szaggatott vonal). Jól látható, hogy a felső fognál jelentősen növekszik a hézag értéke.

A 3. modellnél, amikor a befogó rendszert 3D-s rugalmas végeselemekkel modellezzük, már jóval pontosabb képet lehet kapni a szorító rendszer müködéséröl. A cső súlyát fokozatosan helyezzük rá a megfogóra. Hat terhelési lépcsőt választunk. Az 6. ábra és a 7. ábra a végeselemes felosztást, és az első terhelési lépcsőnél kapott Mises-féle redukált feszültséget mutatja ([MPa] egységben). A 8. ábra a teljes terhelésnél mutatja a pofa elmozdulását, illetve a kialakuló nyomások lefutását (az ábra alján jobbról balról haladva a 4., 3., 2., 1. fogakhoz tartozó görbéket láthatjuk). Mindegyik fognál a felső részen van a legnagyobb nyomás, vagyis itt kell a fogból levenni anyagot (amit az 5b. ábra is érzékeltet), azaz kezdeti hézagot „,gyártani”. 


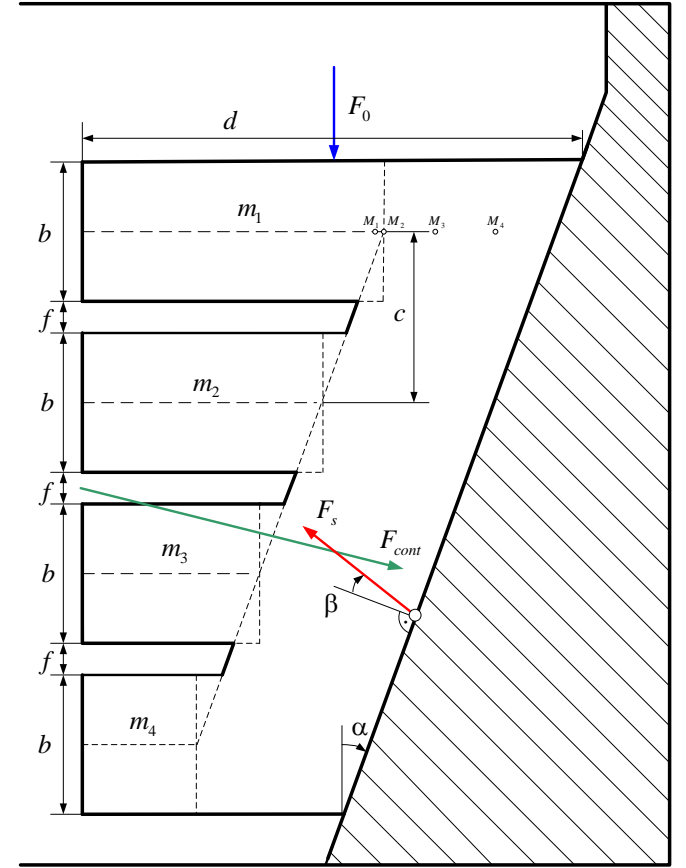

a)

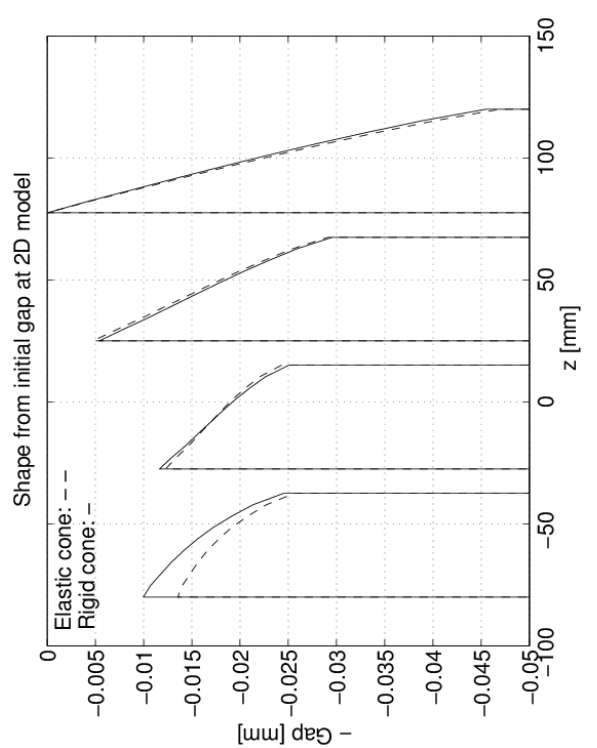

b)

5. ábra. Pofák síkfeszültségi állapotban, a hengeres test rugalmas (2. modell), a) szerkezet, b) a kezdeti hézag.

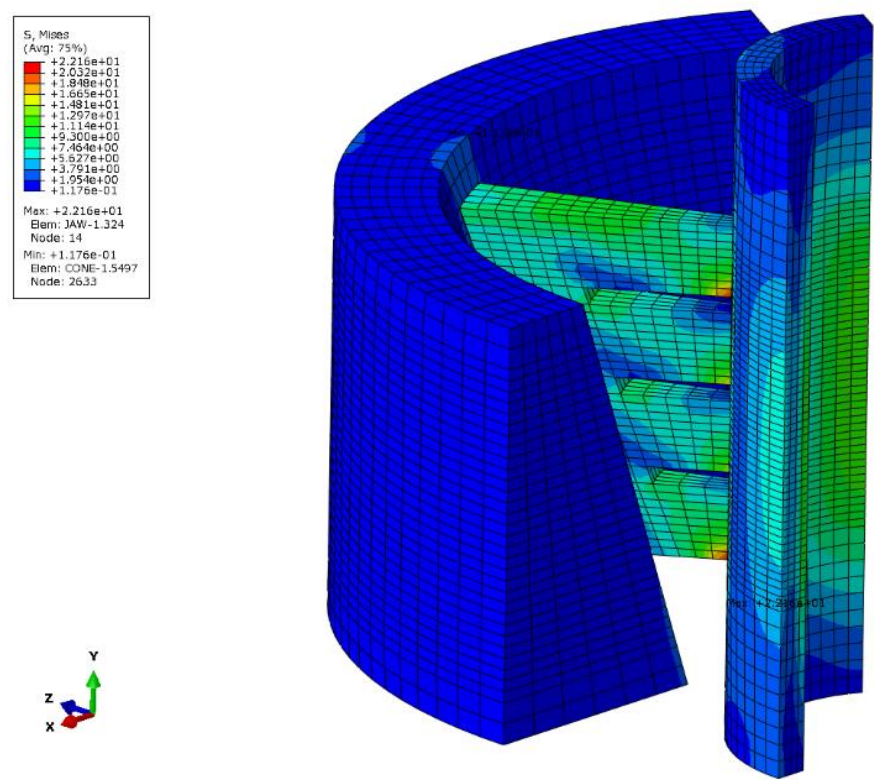

6. ábra. 3D-s vizsgálat, 1. terhelési lépés (Mises-féle redukált feszültségek [MPa]), a teljes szerkezet harmad részében 

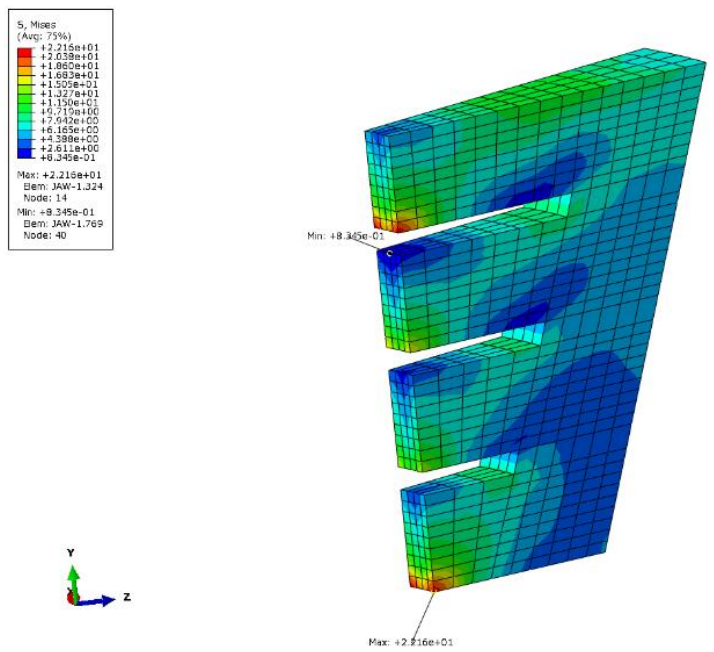

7. ábra. 3D-s vizsgálat, 1. terhelési lépés (Mises-féle redukált feszültségek [MPa]), a szorító pofában

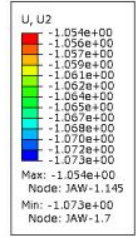

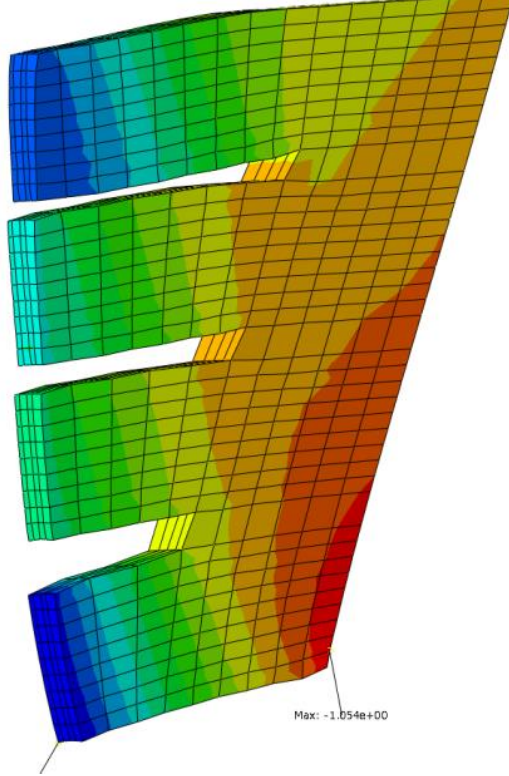

a)

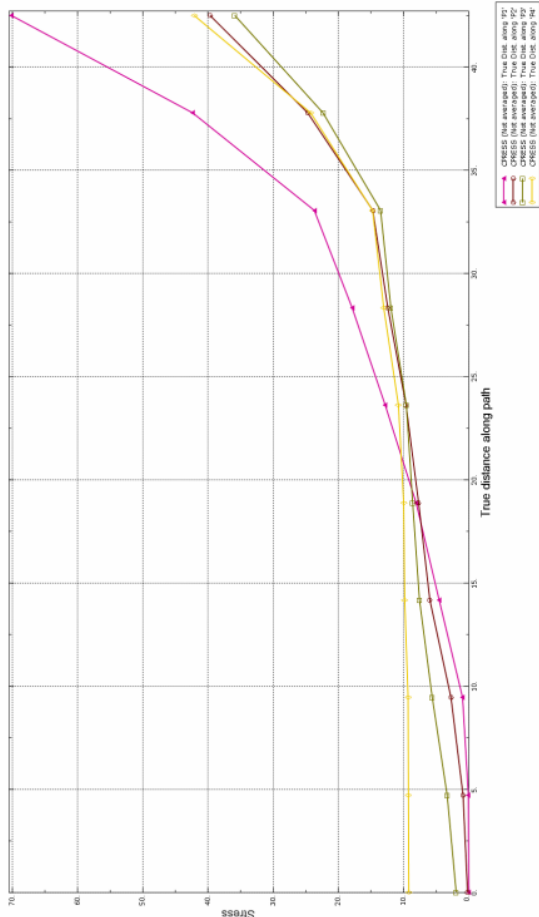

b)

8. ábra. 3D-s vizsgálat, a) elmozdulások [mm] (4. terhelési lépés), b) érintkezési nyomás [MPa] (6. terhelési lépés) 


\section{3. Összefoglalás}

Az érintkezési nyomás vezérlésének technikájával gyorsan meg lehet határozni a kívánt megoszlású érintkezési nyomáshoz tartozó kezdeti hézagot. Mivel a nyomás közvetlenül szerepel a hatásfüggvényt felhasználó iterációs eljárásban, ennek használata előnyösnek mutatkozik a feladat megoldása folyamán. A bemutatott példák jól illusztrálják a javasolt módszer hatékonyságát.

\section{Köszönetnyilvánítás}

A tanulmány elkészítését a Nemzeti Kutatási és Fejlesztési Hivatal (NKFIH) K115701 projektje támogatta. A cikkben ismertetett kutatómunka az EFOP-3.6.1-16-2016-00011 jelü „Fiatalodó és Megújuló Egyetem - Innovatív Tudásváros - a Miskolci Egyetem intelligens szakosodást szolgáló intézményi fejlesztése” című projekt részeként - a Széchenyi 2020 keretében - az Európai Unió támogatásával, az Európai Szolciális Alap társfinanszírozásával valósult meg.

\section{Irodalom}

[1] Páczelt, I.: Some optimization problems connected with contact problems in the linear theory of elasticity, Variational methods in mechanics of solids, Ed. by. S. Nemat-Nasser, Pergamon Press, Oxford, 1980, p. 349-356. https://doi.org/10.1016/B978-0-08-024728-1.50061-6

[2] Haslinger, J. , Neittaanmaki, P.: Finite element approximation for optimal shape design, John Wiley \& Sons Ltd., London, 1988.

[3] Goryacheva, I.G. , Dobuchin, M.H.: Contact problems in tribology, (orosz nyelven), Mashinostroenie, Moscow, 1988.

[4] Banichuk, N.V.: Introduction to Optimization of Structures, Springer-Verlag, London, 2011.

[5] Páczelt, I.: Iterative methods for solution of contact optimization problems, Arch. Mech., 2000, 52, 685 711.

[6] Páczelt, I., Baksa, A.: Examination of contact optimization and wearing problems, Journal of Computational and Applied Mechanics, 2002, 3, 61-84.

[7] Páczelt, I., Mróz, Z.: On optimal contact shapes generated by wear, Int. J. Num. Meth. Eng., 2005, 63, 1310-1347. https://doi.org/10.1002/nme.1321

[8] Páczelt, I., Mróz, Z.: On the analysis of steady sliding wear process, Tribology International 2009, 42, 275-283. https://doi.org/10.1016/j.triboint.2008.06.007

[9] Johnson, K.L.: Contact Mechanics, Cambridge Univ. Press, Cambridge, U.K., 1985.

[10] Kalker, J.J.: A course of contact mechanics, a79C, Delft University of Technology, 1985.

[11] Konyukhov, A, Schweizerhof, K.: Computational Contact Mechanics. Springer-Verlag, Berlin, 2013. https://doi.org/10.1007/978-3-642-31531-2

[12] Wriggers, P.: Computational contact mechanics, John Wiley and Sons, New York, 2002.

[13] Páczelt, I., Mróz, Z.: Optimized punch contact action related to control of local structure displacement, $\begin{array}{lllll}\text { Structural and } & \text { Optimization, } & \text { 2019, } & \text { 60, }\end{array}$ https://doi.org/10.1007/s00158-019-02300-Z 